\title{
UNIVERSITYOF
}

FORWARD

THINKING

WESTMINSTER ${ }^{\text {用 }}$

WestminsterResearch

http://www.westminster.ac.uk/westminsterresearch

Regimes of Temporality: China, Tibet and the Politics of Time in the Post-2008 Era

Kehoe, S.

This is a copy of the accepted author manuscript of the following article: Kehoe, S. (2020) Regimes of Temporality: China, Tibet and the Politics of Time in the Post-2008 Era. Media Culture and Society. Advanced online publication.

doi:10.1177/0163443720907535.

The final definitive version is available from the publisher Sage at:

https://dx.doi.org/10.1177/0163443720907535

(C) The Author(s) 2020

The WestminsterResearch online digital archive at the University of Westminster aims to make the research output of the University available to a wider audience. Copyright and Moral Rights remain with the authors and/or copyright owners.

Whilst further distribution of specific materials from within this archive is forbidden, you may freely distribute the URL of WestminsterResearch: ((http://westminsterresearch.wmin.ac.uk/)).

In case of abuse or copyright appearing without permission e-mail repository@westminster.ac.uk 
Journal of

Media, Culture \& Society

\section{Regimes of Temporality: China, Tibet and the Politics of Time in the Post-2008 Era}

\begin{tabular}{|r|l|}
\hline Journal: & Media Culture and Society \\
\hline Manuscript ID & MCS-2019-409.R2 \\
\hline Keyword: & China, Tibet, Temporality, Media, Discourse, Ideology \\
\hline & $\begin{array}{l}\text { Following major protests across Tibet in 2008, Chinese state media } \\
\text { published dozens of news stories that attempted to discredit protesters } \\
\text { and reaffirm Chinese rule over Tibet. The relationship between Tibet's } \\
\text { past, present and future was a central focus across these stories and has } \\
\text { since become an increasingly prominent part of state media reportage } \\
\text { about Tibet. While the politics of time are an important dimension of } \\
\text { official discourse about Tibet, it remains insufficiently explored in } \\
\text { theoretical and practical terms. This article examines the written and } \\
\text { visual discourses that characterize Tibetan temporality across Chinese } \\
\text { state media in the post 2008 era. Following Poell's (2018) work, I } \\
\text { analyse how these media discourses attempt to construct a 'regime of } \\
\text { temporality' in order to manage public opinion about Tibet and } \\
\text { consolidate Chinese rule over the region. However, while the expansion } \\
\text { of online technologies has allowed the state to reinforce its discourses } \\
\text { about Tibet's place within the PRC, they have also provided Tibetans a } \\
\text { limited but valuable space to challenge official representations. In doing } \\
\text { so, this article contributes to discussions about official media strategies } \\
\text { and ideological practices in contemporary China, and considers the } \\
\text { disruptive potential of social media as spaces for Tibetan counter } \\
\text { discourses. }\end{array}$ \\
\hline Abstracter
\end{tabular}

\section{SCHOLARONE" Manuscripts}


In January 2009, the People's Congress of the Tibet Autonomous Region (TAR) voted to establish Serf Emancipation Day as a new public holiday to commemorate the end of Tibet's 'feudal serfdom system' and 'the start of Tibetan democracy' in 1959 (China Daily, 2018). The new holiday would be observed on March $28^{\text {th }}$, also marking the $50^{\text {th }}$ anniversary of China's defeat of the Lhasa Uprising, which led to the dissolution of the Tibetan government and the Dalai Lama's flight into exile. Introduced just months after largescale protests erupted across Tibet $^{1}$ in 2008, the decision was criticised by activists and scholars as a distortion of history and a provocative move that could aggravate tensions at a time of already heightened Tibetan sensitivity (GrahamHarrison, 2009). Now a decade on, Serf Emancipation Day is held annually and receives considerable attention from Chinese state media.

This new holiday represents just one part of the Chinese state's intensified efforts to reaffirm its territorial claims over Tibet in the post 2008 era through a tightened grip on the narration of the region's past, present and future. Although stories of Tibet's transformation from 'hell on earth' to 'socialist paradise' under Chinese Communist Party (CCP) rule have featured across state media since 1959 (Powers, 2004; Warner, 2011), this politics of time has become an increasingly prominent dimension of official representations of Tibet since 2008. The expansion of online technologies has been significant in this, providing the state new ways to consolidate its narratives about Tibetan temporality. However, online technologies have also provided Tibetans a limited but valuable space to challenge official representations. Given the emergence of online spaces as a new discursive battleground in the representation of Tibet, how has the state harnessed new media platforms to construct and promote discourses of Tibetan temporality, and how have Tibetans engaged these platforms to promote counter discourses? 
This article examines written and visual discourses of Tibetan temporality across online media in post 2008 China. Using multimodal discourse analysis, I analyse the various ways in which Chinese state media mobilize time to reinforce Tibet's place within the PRC. Using Poell's (2018) term 'regime of temporality' to describe the convergence of power, ideology and media in the production and ordering of time, I argue that discourses of temporality are an important state media strategy that attempt to manage public opinion about Tibet while also contributing to broader efforts to reinforce Chinese rule over the region. I also examine how Tibetans use online platforms to contest official representations and create new spaces to reimagine Tibet's past, present and future. In doing so, this article contributes new insights on the production of state power over Tibet, online media practices in China, and the disruptive potential of Tibetan counter discourses.

\section{Regimes of Temporality}

If time describes particular moments or 'instants of now', then temporality is the passage of time, or the ways in which 'now' moments 'connect and relate to other periods in a backward (past) and forward (future) direction' (Dawson, 2014: 286). Ideas about time and temporality are shaped by political, economic, social, and cultural values and practices (Assman, 2013: 42), and have 'the power to control movements, to decide about beginnings and endings, [and] to set the pace' (Jordheim, 2014, 510). Time, then, can be deeply political, creating a temporal 'order of things' that regulates actions across space and bodies (Foucault, 1970: 320). 
Scholars working across a range of socio-political contexts have theorised the significance of time for the state. Anderson (1983: 26), for example, analysed how nations are built around a shared sense of 'a solid community moving steadily down (or up) history'. Similarly, Mitchell (1991: 95) argues that states can be understood as a process of 'temporal arrangement', deploying selective representations of past, present and future for political ends. Particularly relevant to contexts like Tibet, scholars in colonial and postcolonial studies describe time and temporality as key facets of colonial governmentality. The imposition of one time, posits Mignolo (2002: 67 ), functions 'as a principle of order that increasingly subordinates places, relegating them to before or below from the perspective of the 'holders (of the doors) of time'. Here, temporality produces hierarchy, structuring relations between the colonizer and the colonized by characterizing the colonized as 'waiting', 'lagging behind' or 'catching up' (Chakrabarty, 2000). Through the construction and management of chronological narratives, time represents a powerful political resource that reduces heterogeneous temporal experiences to a single, shared trajectory of unilinear progress in order to consolidate order and control.

Such national temporalities require constant reproduction. Bhabha (1994: 232) argues that any singular national temporality is founded on 'disjunctive' narratives, destabilized by the contradictions between those who write them and those who live them. States must constantly work to reproduce themselves through repetitious and recursive performances. This may be enacted through regular 'national' rituals such as education, public monuments, museums or commemoration days like Serf Emancipation Day.

As a powerful vehicle for shaping social, cultural and political practices, media is crucial to the production of discourses about temporality. Scholarship on the 
relationship between media and temporality has largely focused on how the expansion of media technologies has collapsed time-space distanciations and precipitated the 'timeless time' of a global digitally networked and interconnected world (Harvey,1989; Castells, 1996: 464). However, media is also a powerful site for generating and disseminating messages about temporality. In his work on political communication, Poell (2019: 2) argues that when specific media institutions, infrastructures, and practices come to dominate the media landscape, particular kinds of temporality are produced and become significant in shaping 'societal sense-making processes during particular periods.' As such, 'regime of temporality' describes how media, power and ideology intersect to shape 'temporal orientations' towards present, past, and future (Poell, 2019: 7).

\section{China, Temporality and State Media}

Chinese state media provides a fitting case study on the convergence of media, power and temporality. Since the establishment of the PRC in 1949, discourses of temporality have been an important tool for promoting national cohesion. The new Communist state quickly dispensed with the five official time zones that had existed under the Nationalist government and introduced 'Beijing time' as the new standardized time regime, a political move designed to assert power and enhance control (Hassid and Watson, 2014). While a minor inconvenience for most, alignment to Beijing time in China's far western regions has been much more complicated, leading to the emergence of informal temporal arrangements, such as 'Urumqi time' (two hours 
behind Beijing time). Time was also used to cultivate a national historical consciousness that celebrated China's linear progression from national humiliation to national salvation under the leadership of the CCP (Callaghan, 2004). These official narratives of Chinese history rested upon selected figures, images and dates, organised retrospectively 'with the self-professed purpose to prove the inevitability and legitimacy of Communist rule' (Wu, 2005: 134). However, while the Mao era centred on 'schemes of accelerated socialist transformation' and modernist certainties of linear development (Anagnost, 1997: 7), the new modes of production, consumption and socio-cultural norms that followed the economic and social reforms from the late 1970 s onwards generated various forms of temporal dissonance and fragmentation, unsettling narratives of a homogenous national time (Dirlik and Zhang, 2001).

New strategies were required to negotiate these conflicting narratives of temporality and consolidate a new national vision for the post-socialist era. While during the Mao era media was a key arena where the state could manipulate 'the spatial and temporal dimensions of news to suit the state agenda on certain issues,' media marketization during the reform era meant official discourses would now compete with monthly magazines, weekend supplements and tabloid papers (Sun, 2001: 26). Online technologies have further challenged the state's attempts to maintain a monopoly over media narratives. As part of efforts to adapt to the country's fast-changing media landscape, China's propagandists have increasingly stressed the importance of official media going online and digitalizing content (Brady, 2009: 441).

Reconfigurations of power and ideology since the Hu-Wen era have renewed emphasis on ideology, propaganda and political discourse to enhance domestic stability and strengthen one-party rule (Klimeš and Marinelli, 2018). Online media management and content production are important elements of this, used to ensure 
that information reaching the public does not 'inspire people to challenge party rule' (Shirk, 2011: 3). These practices increasingly entail sophisticated methods of 'digital persuasion', which aim 'to sway public opinion in favour of the party' (Repnikova, 2017: 147). As such, while the pluralisation of news media outlets has challenged the state's traditional stronghold over information production and dissemination, state media has quickly adapted to secure their base through new forms of public opinion management.

While China's propaganda system has largely moved towards banning fewer reports and guiding more of them (Tai, 2014: 186), areas with high shaoshu minzu (broadly translated as 'ethnic minority') populations remain disproportionately targeted by censorship. Bamman, O'Connor and Smith (2012: 2) claim that Weibo messages originating in Tibet, Qinghai and other areas in western China are subject to much higher deletion rates (53\%) than those in eastern provinces (ca. 12\%). In March 2018, government authorities instructed media platforms to 'pay attention to online information related to Tibet' and advised that any 'harmful information' be promptly reported to avoid stirring up 'negative public sentiment regarding Tibet' (China Digital Times, 2018). This combination of heavy censorship, ideology and propaganda has serious implications for media discourses about Tibet. As this article demonstrates, state media's online production of a regime of temporality is one notable example, illustrating the intersection of media, power and ideology to guide public opinion and consolidate state power over Tibet.

\section{Tibet and Discourses of Temporality}


Of the more than one billion people that make up the population of the PRC today, 92 per cent are Han, while the remaining 8 per cent are officially recognised as shaoshu minzu. Scholars have noted how shaoshu minzu are normatively ordered within an ideological system where the Han are represented as the advanced, modern minzu (broadly translated as 'ethnic group' or 'nationality'), and shaoshu minzu as the backward, child-like and even exotic ethnic other (Schein, 1997; Harrell, 1996; Gladney, 1991;). Ethnic difference, then, is deeply temporal, with shaoshu minzu positioned at different evolutionary stages on the path to national socialist modernisation and in need of guidance from the 'elder' Han to progress.

Perhaps nowhere in the PRC are the politics of minzu and time quite so prominent as in the case of Tibet. While Tibetans are subject to the same temporal hierarchy as other shaoshu minzu, they contend with additional issues surrounding Tibet's historical relationship with China. Although the Chinese state continues to hold steadfastly to its claims that Tibet has been an inalienable part of China since the Yuan Dynasty, this has been variously challenged (Shakya 1999; Powers, 2004; Sperling, 2009a). Further intensified by public calls for independence, the Tibetan government in exile, and the international reputation of the Dalai Lama, the issue of history has become a point of particular sensitivity in China's campaign to assert its rule over Tibet (Sperling, 2009a: 25).

Time has not always been such a prominent component of Chinese propaganda about Tibet. After the CCP asserted control over the region in 1951 through 'peaceful liberation', it was decided that Tibet would be gradually incorporated into the newly established state (Chen 2006: 63). The 1951-1959 period was characterised by moderation where a new socialist Tibet was to be built under the combined leadership of the CCP, the State Council, the Dalai Lama, Panchen Lama, 
and CCP Tibet Working Committee (Zhang, 1957). While 'feudal serfdom' is occasionally mentioned in media pieces about Tibet during this time, much greater emphasis is placed upon the need to "raise revolutionary consciousness and resolutely oppose imperialism" (People's Daily, 1952). This changed in 1959 following the Lhasa Uprising, which marked a decisive challenge to Chinese rule in Tibet, and 'elicited clearer and more forceful formulations of the PRC's position on Tibet's historical status' (Sperling, 2009: 28).

Since 1959, state media has been an important element in reinforcing Chinese rule over Tibet. In the immediate aftermath of the Lhasa Uprising, state media produced a wave of articles that variously proclaimed 'backward, dark and brutal old Tibet' had 'already become the past' (People's Daily, 1959). The same year Millions of Serfs Arise (Baiwan nongnu zhanqilai, 1959), a documentary about democratic reform, was released. This was followed by The Serf (Nongnu, 1963), a film depicting a mute Tibetan serf who regains his voice following the abolishment of 'feudal serfdom'. Such references to transformation in post 1959 Tibet continued throughout the Mao era across literature and the arts (Dondhup, 2017: 106). The story of Princess Wencheng, one of the Chinese consorts sent to the Tibetan emperor Songtsen Gambo in the $7^{\text {th }}$ century to pacify relations along China's borders, became especially prominent at this point, and has since been variously adapted in folk songs, operas, books, film, and television to emphasise 'ethnic unity' (minzu tuanjie) and Tibet's historic dependency on China (Warner 2011; Bulag, 2002). Such historical instances of contact between China and Tibet are presented as 'evidence of Chinese overlordship' and used to reinforce ideological claims that Tibet has belonged to China for centuries (2004: 35). Between 1987 and 1989, responding to protests in Lhasa commemorating the $30^{\text {th }}$ anniversary of the Lhasa Uprising, state media again 
produced dozens of pieces reiterating that Tibetans were 'part of the Chinese nation' (Zhu, 1989) and emphasising that 'only through following the path to socialism can Tibet have a bright future' (Lu, 1989). More recently, monuments (Harris, 2012) and museums (Dodge and Keränen, 2018) have also become core sites in shaping public memory and making temporality-based claims about the legitimacy of Chinese rule in Tibet.

While not completely new, representations of Tibetan temporalities across Chinese state media have increased sharply since Spring 2008 when protests again erupted across Tibet. These protests were a response to frustrations, inequalities and broken promises arising from the 'Open the West' (Xibu da kaifa) campaign, which began in 2000 and seeks to advance economic development across China's western regions, and were also an expression of longstanding issues surrounding the legitimacy of Chinese rule in Tibet (Hillman, 2014; Shakya, 2012). The unrest continued across Tibet for months with demonstrations by monks and students, clashes between Tibetans and the police, and dozens of self-immolations since 2009 (Hillman, 2014: 54). These events attracted considerable international attention, challenging official claims of ethnic unity and state legitimacy, and resulting in an increasingly hard-line position on Tibet's historical status (Sperling, 2009a). Since then, state media has played a key role in reaffirming and galvanizing Han support for Chinese rule across the region. As this article shows, online spaces have become an important new avenue for the dissemination of these discourses, with visual images playing a central part in the production of the state's regime of temporality for Tibet. 


\section{Methodology}

This article analyses online publications from China's major state media such as People's Daily, Xinhua, and CCTV (Zhongguo zhongyang dianshi-tai) and other influential official media platforms. Articles were collected through China National Knowledge Infrastructure's (CNKI) China Core Newspapers Full-text Database, which covers China's main official news agencies. For texts produced by Tibetans, I used Tibetcul, one of the most popular and longest running Sinophone Tibetan websites in China and covering a wide range of topics, including literature, current events and religion. Tibetcul is particularly useful for this study because it is dedicated to promoting dialogue about Tibet across China. I also use Weibo, one of China's main social media platforms, focusing again on Tibetan participation in broader Sinophone discourses about Tibetan temporality. As such, this study is not a comprehensive overview of all Tibetan discourses of temporality, focusing instead on Tibetan efforts across online spaces to advance counter discourses to Chinese audiences.

Seeking to examine how the state has intensified its temporal claims over Tibet in the wake of the 2008 unrest and how it is increasingly using new online media forms to achieve this, this paper focuses on texts produced between March 2008 and March 2019. Texts were searched by headlines that included democratic reforms, old Tibet, new Tibet, and other terms relating to Tibet's temporal development. Searching by headline helped to downsize search results and build a corpus of texts that engaged most substantially with the topic (Sriwimon and Zilli, 2017: 140). The CNKI database produced 671 state media pieces, from which a sample of 30 were randomly selected 
for analysis. For texts produced by Tibetans, a total of 183 were found, of which 30 were again randomly selected for analysis.

Critical Discourse Analysis (CDA) and Critical Multimodal Discourse Analysis (CMDA) were used to analyse written and visual texts. Both approaches examine ideological practices across political speeches, news items and other forms of media texts in order to demystify systems of power. While CDA focuses on written and verbal practices of language (Wodak, 1995), CMDA investigates the role of visual semiotics in media texts such as images and videos (Van Leeuwen and Jewit, 2014). Given the centrality of visual images across official and Tibetan online discourses of temporality, combining CDA and CMDA provides a suitable approach for examining how different forms of media texts work together to create and reproduce different kinds of ideological and political power. Following Wang's (2014) adaption of Fairclough's three-dimensional discursive analysis approach of description, interpretation and explanation, texts were then analysed for references to agents, time and tense, modality, and syntax, as well as visual composition and corporeal elements such as subjects, objects, instruments, and activities.

\section{Chinese State Media Discourses}

During and immediately after the Tibet protests in March 2008, Chinese state media focused on the number of non-Tibetan casualties and damage to property, blaming 'separatists' inside and outside Tibet for the unrest, and commending security forces for restoring order. The subsequent weeks witnessed dozens of state media pieces 
attempting to deflect western media's accusations of human rights abuses as explanations for the protests by emphasising the progress Tibet has made under CCP rule. It is here that written and visual depictions of Tibet's past, present and future become particularly prominent across state media discourse.

Most state media reportage about Tibet make at least some passing reference to the changes that have taken place across Tibet since 1959. Since 2008 considerably more attention has been given to contrasting 'old Tibet' (before 1959) and 'new Tibet' (after 1959). These articles place significant emphasis on stories of oppression and suffering in 'old Tibet' to showcase what they claim was the cruelty of Tibet's political and social order prior to 1959. This can be observed from news story titles alone:

Tibetan History: The Tragic Life of Tibetan People under Feudal Serfdom (Xinhua, 2008)

The Dark, Brutal Serfdom System of Old Tibet (Xinhua, 2009)

Valuable Historical Cases and Evidence: The Feudal Serfdom Was One of the Darkest Pages in the History of Humankind's Development (People's Daily, 2015)

Bearing striking similarity to pieces used in the aftermath of the Lhasa Uprising, state media reportage since 2008 uses language such as 'dark', 'cruel' and 'tragic' to describe Tibet prior to democratic reform. However, these pieces often go much further than those of 1959 by including detailed accounts of Tibetans 'doing labour in shackles' (People's Daily, 2015), being 'beaten to death' (People's Daily, 2013), and torture practices such as 'gouging out eyeballs, chopping off hands, cutting off feet, and skinning' (People's Daily (2008b). New discourses also characterise 'old Tibet' as 
an exceptional and unparalleled regime of tyranny, 'even worse than the serfdom of medieval Europe' (People's Daily, 2008a). As a further innovation upon past media strategies, these pieces generally include several photographs to reinforce 'old Tibet' as a place of extreme brutality. Images regularly feature whips, amputated limbs, and people in chains to visualise abuse and suffering under Tibet's 'feudal serfdom' (Fig. 1), along with detailed written accounts of how such tools were used by Tibetan landowners to torture Tibetan 'serfs' (Fig. 6).

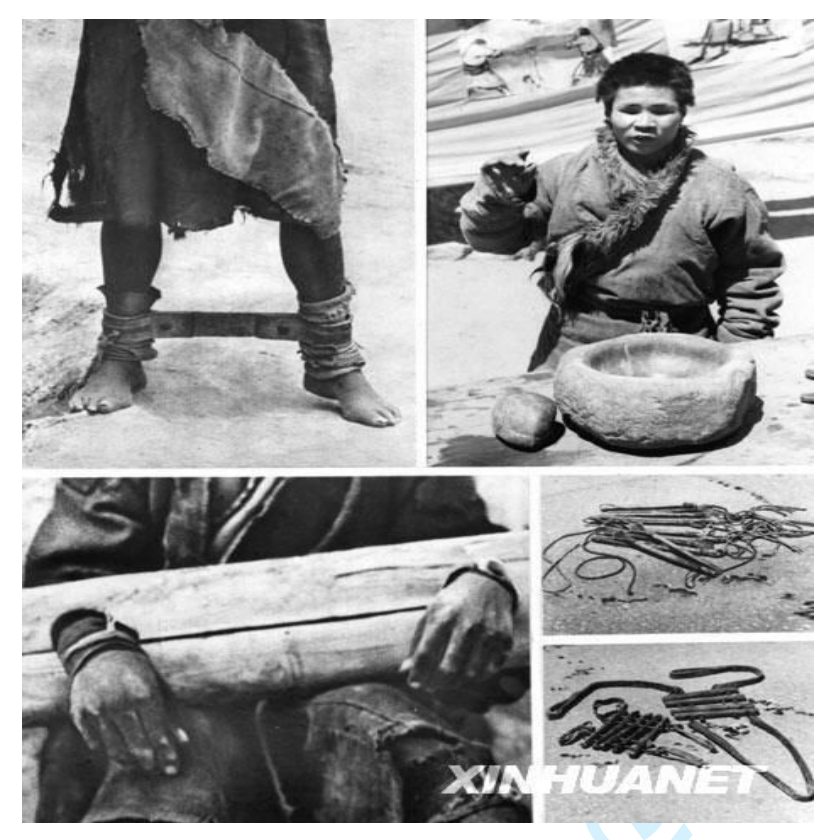

Fig. 1 Images of implements used to torture Tibetan 'serf' (Xinhua, 2009)'

Representations of 'old Tibet' often appear alongside glowing depictions of 'new Tibet'. While 'old Tibet' is represented as a 'hell on earth' full of oppression, backwardness, and darkness, 'new Tibet' is depicted as democratic, free and reaping the benefits of socialist transformation. Within this narrative, 1959 is referenced as a 'turning point' (zhuanzhedian), when Tibetans 'overturned' (fanshen) their fate under a 'feudal serfdom' and embarked on a new path towards socialist modernisation under CCP rule. 1959 is described as a pivotal moment in Tibet's 'liberation' from 'feudal serfdom' through repeated references to 'Tibetan society prior to 1959' (Hu, 2016) and 
'after Tibet's democratic reform in 1959' (Tibet.cn, 2016). This constructs a clear temporal distinction between 'old Tibet' and 'new Tibet', positioning them as 'radically opposed epochs' (Kolås, 1998: 22).

The visualisation of Tibetan temporality is especially manifest in state media juxtapositions of 'old Tibet' and 'new Tibet'. The most well-known example of this is 'Contrasting New and Old Tibet', a series of short videos produced by Tibet TV, the official television channel of the TAR (Tu, Zhao and Li, 2015). Running from 2012 to 2017, these videos were broadcast daily on Tibet TV and were also posted to CCTV's website. Centring around the personal testimonies of older Tibetans, the videos begin by describing experiences of suffering in 'old Tibet', typically focusing on instances of hard labour, lack of food and lack of land ownership, before shifting to describing the progress and happiness experienced after democratic reform (Fig. 2). In one episode (CCTV, 2017), an elderly Tibetan woman recounts her experience to a group of young Tibetans about the 'hardships of old Tibet' where people did not have enough food or warm clothes. The story quickly moves on to describing the economic development brought to her village by the CCP (Fig. 3). The recurrent use of black and white images for 'old Tibet' and colour images for 'new Tibet' throughout these videos is an important media strategy that further enhances the sense of temporal rupture between the two eras, while the use of personal stories and first-hand accounts from those who experienced Tibet before and after 1959 serves to humanise propaganda work, and boost overall persuasiveness. 


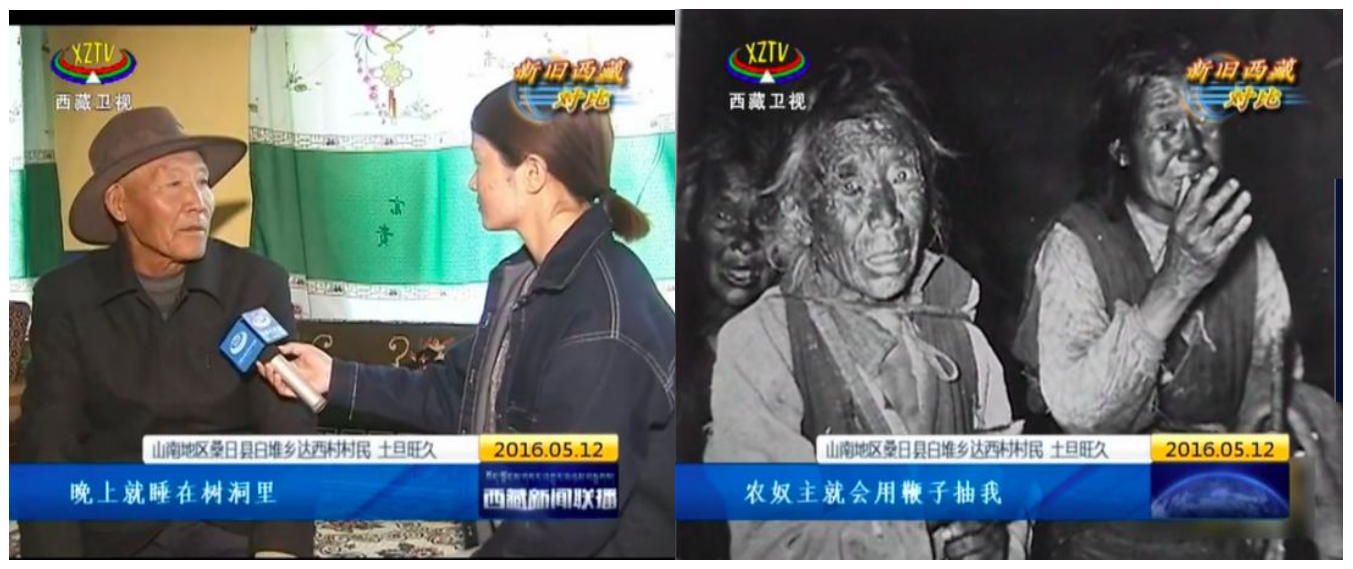

Fig. 2 Screenshots from 'Contrasting New Tibet and Old Tibet' (CCTV, 2016)

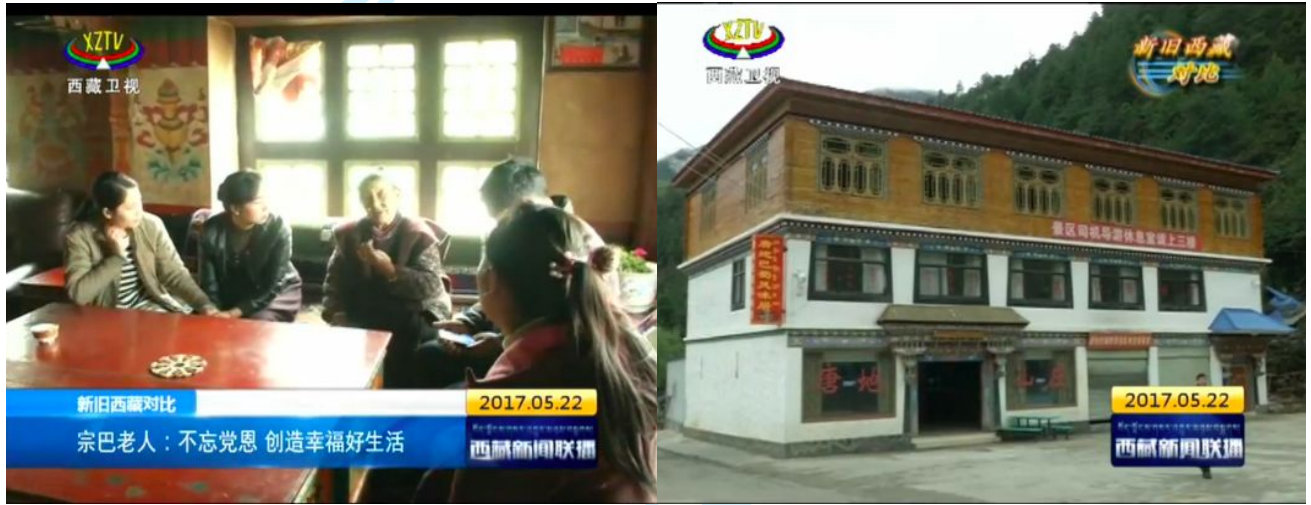

Fig. 3 Screenshots from 'Contrasting New and Old Tibet' (CCTV, 2017)

These discourses reinforce a temporal order based on a linear story of progress since 1959, but also look to the future. Tibet is characterised as 'thriving on a path of rapid modernization' (Xinhua, 2019) and striving towards 'an even brighter future' (People's Daily, 2019). Tibet's future and the CCP are closely bound together across these texts. In one Tibet Daily (2018) piece, Mingji Cuomu, the vice president of Tibet Medical College, is quoted as saying:

Without the Chinese Communist Party, there could be no new Tibet. Only the Chinese Communist Party can save Tibet and develop Tibet.

Similar discursive techniques are found across official texts. One white paper, widely circulated across state media, declared that democratic reform in Tibet was an 
'historical inevitability' and proclaimed that 'the destiny of Tibet has always been closely connected with the destiny of the great motherland and the Chinese nation' (China Daily, 2015). Here, the discursive containment of Tibet within the march towards Chinese socialist modernity is especially evident. Yet, despite its apparent 'historical inevitability', Tibet's future requires constant defence from external threats. Warnings about what Tibet might become were the 'Dalai lama clique' to regain power are a common feature across these media pieces, often centring on a return to 'old Tibet' through the re-establishment of 'a theocratic feudal serfdom,' as Zhu Weiqun, a former deputy head of the CCP's United Front Work Department, has cautioned (People's Daily, 2009). These discourses attempt to persuade readers of the necessity of rejecting what they argue to be the regressive aspirations of 'separatists' in the interest of protecting Tibet from once again becoming a 'hell on earth.' In this way, they serve as a powerful discursive tool in constraining, excluding and undermining alternative narratives of Tibetan temporalities that contradict those of the state.

While often echoing discursive strategies from 1959 and 1989, state media is increasingly sophisticated and diverse in its discourses about Tibet with new media technologies enabling new ways of visualising Tibetan temporalities. Tibetan pop music and music videos, for example, have been variously appropriated and co-opted by the state to reinforce official discourses (Morcom, 2018). In 2019, to mark Serf Emancipation Day, the People's Daily realised a music video to the tune of 'Me and My Motherland'. Featuring several well-known Tibetan celebrities and 'model workers', the video opens with an elderly woman visiting an exhibition depicting life in a Tibetan village before and after democratic reform. In the next scene, Tibetans gather on the streets to sing together as they wave Chinese flags (fig. 4). The video was widely 
circulated by state media across Weibo and Wechat, and various spinoffs were produced for different cities across Tibet.

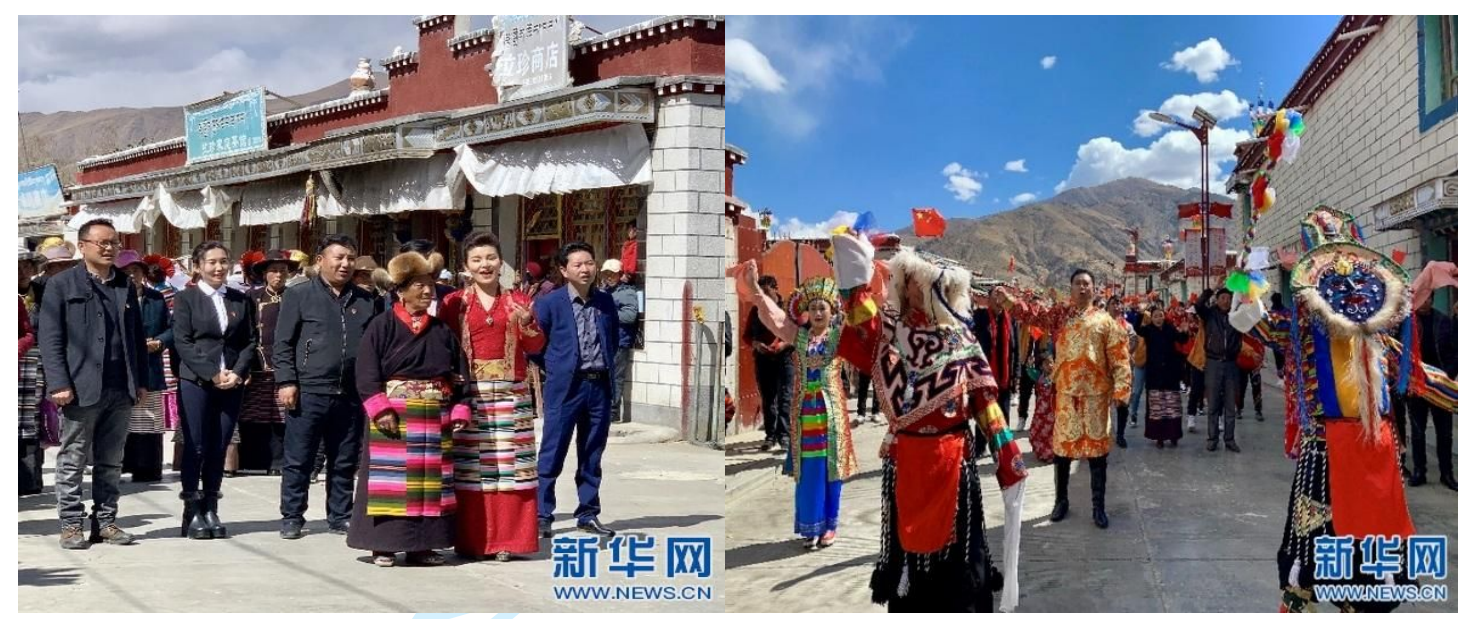

Fig. 4 Images of 'Me and My Motherland' music video (Tibet.cn, 2019)

With new opportunities afforded by social media platforms, state media official accounts have also started to engage with other forms of online technologies in their coverage of Serf Emancipation Day. In 2019, alongside livestreaming parades in Lhasa and Shigatse, People's Daily, Xinhua and other official media platforms used the hashtag \#2019XizangBaiwanNongnuJiefangJinianri\# (2019 Anniversary of the Liberation of Tibet's One Million Serfs) to increase the visibility of official celebrations across social media. State media posts on Weibo and Wechat have also included clips from documentaries such as '50 Years of Tibet's Democratic Reforms' (Xizang minzhu gaige 50 nian) (CCTV, 2009) as embedded GIFs (graphic interchange format). In this way, Chinese state media are constantly adapting new and diverse media technologies to reinforce the state's regime of temporality over Tibet and consolidate Chinese rule and legitimacy. 


\section{Tibetan Counter Discourses}

Like people everywhere, Tibetans have been narrating their own histories for centuries. Shaped by internal and external logics, contradictions, and conflicts across different time and space, these narrations variously centre the reincarnation of eminent lamas (Makley, 2018: 183), monastic moral development and decline (Caple, 2019), nature stories (Yeh, 2009) and so on. Following increased references to Tibet's past, present and future across Chinese state media in the post 2008 era, counter discourses have become another popular form of time-telling among Tibetans in online spaces.

Just as online media provide a space for the state to produce and circulate discourses of temporality in order to consolidate Chinese rule and legitimacy in Tibet, so too does it offer Tibetans a platform to form and disseminate counter discourses to audiences across China. Despite censorship and the threat of arrest for those who cross the line of permissible expression in China's online spaces, creative strategies and coded references have allowed even the most sensitive of topics, such as selfimmolation, to be discussed (Robin, 2012: 123). The use of visual images is one such strategy that enables Tibetans to engage state representations of Tibetan temporality.

Sharing photo essays of 'old Tibet' is a common online practice. These essays cover everything from fashion, sports, the Tibetan army, to landscapes and architectural landmarks in early $20^{\text {th }}$ Tibet century. Many of the images used in these photo essays appear to have been sourced from The Tibet Album, a virtual collection of over 6000 images of early $20^{\text {th }}$ century Tibet at Pitt Rivers Museum, University of Oxford. However, the ways in which these photo essays are compiled rarely reflect their original arrangement on The Tibet Album. Instead, the essays are often highly 
de-contextualised, with little information beyond a location and the year the image was taken, and are compiled in such a way to tell a story about one particular issue.

One of the most influential and active producers of photo essays is Lingka Luorong Zeren, a Tibetan man from Dartsedo (Ch. Kangding). Since 2007 Zeren's has posted over 300 essays. Of these, his photo essays are the most popular and attract thousands of views and shares. His essays portray Tibet as a functional political and economic system and as a globally integrated and culturally rich society. They feature marketplaces in Lhasa, soldiers, monks, pilgrims, entertainers, government officials of the Qing and Kashag (the governing council of Tibet under the Qing), and Tibetan women working in various contexts (Fig. 5) (2013a). In one of his most popular essays, Zeren (2013b) presents images of Tibetans wearing Chinese and Western clothing, using microphones and gramophones, and describes such practices as 'modern' (xiandai) (Fig. 6). Through written and visual descriptions, Tibetans are portrayed as active participants in their history, rather than wholly oppressed and exploited victims.
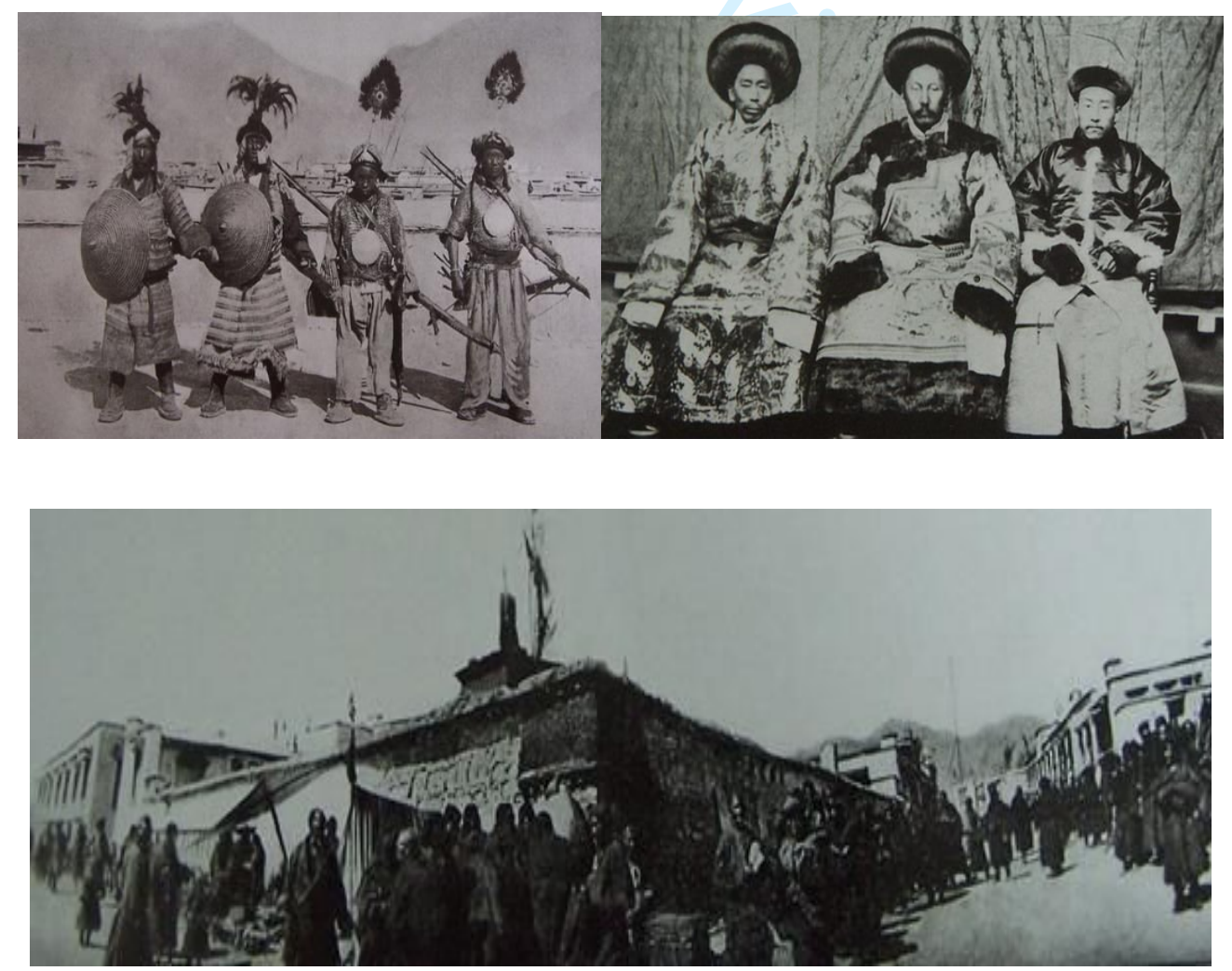
Fig. 5 Images from 'Old Photographs of Lhasa: Fashion in the 1940s (Zeren, 2013a)
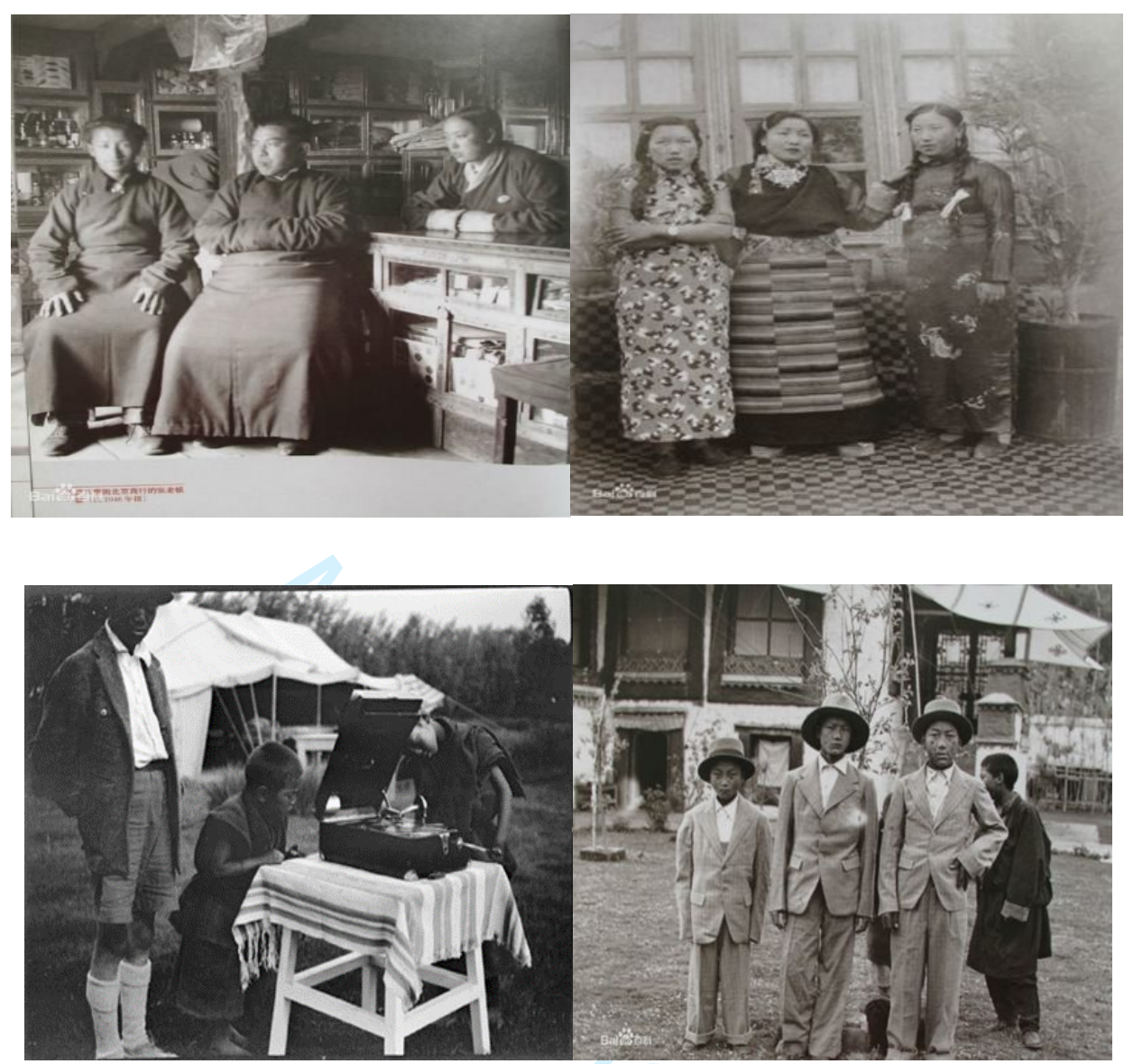

Fig. 6 Images of 'Old Photographs of Lhasa: Fashion in the 1940s (Zeren, 2013b)

These essays omit any mention of 'feudal serfdom', torture or suffering, all of which, as seen above, dominate official representations of 'old Tibet'. Often indicating a wider context within which less factually accurate accounts are produced and circulated, Zeren and his audience present 'old photo' essays as portraying 'real history' (zhenshi de lishi) and an alternative to state propaganda. The images are described as a way of 'pulling history and the present closer together' and as 'a bridge that link the past and the present.' In contrast to state media discourses of temporality that focus on clear temporal distinctions between 'old Tibet' and 'new Tibet', Tibetan counter discourses instead articulate desire for connection and continuity across time. Against an official discourse that continually and actively works to discourage positive 
associations with 'old Tibet', these discourses allow Tibetans to snatch 'from the hidden histories another place to stand in, another place to speak from' (Hall 1991: 123). Such photo essays restore elements of Tibet's past that have been erased by state media. In doing so, they 're-story' the past' and create new spaces to "re-imagine' the future' (Espinoza and Harris, 1997:1585).

Visual images are sometimes used to challenge state media representations in even more direct ways. After state media accounts on Weibo marked Serf Emancipation Day in 2017 with their usual selection of images of Tibetans being exploited and punished by landowners in 'old Tibet', a number of Tibetan accounts contested this narration of Tibet's past by posting images of the Qing Dynasty. Xire Duoji, a Tibetan scholar and active Weibo user, responded to one CCTV News post by arguing that 'the social order of old Tibet and that of the Qing Dynasty were the same; they were both feudal serfdoms,' critiquing the state's persistent singling out of 'old Tibet' as uniquely brutal. Nine Flavours of Anshen Tea (Jiuwei Anshen Cha), a popular Tibetan Weibo account dedicated solely to sharing pictures of Tibet prior to the Chinese invasion, posted several images from the Qing era of people being tortured (Fig. 7), and wrote that 'these images are also of those things in the Qing Dynasty, but that is absolutely not the whole story of the Qing Dynasty.' Anshen Tea's post was shared hundreds of times among Tibetans, variously recaptioned with phrases such as 'Old China: One billion serfs' and 'Have the Han serfs been liberated yet?' Here, Tibetans overtly and playfully mimic state media discourses and ridicule the distortive ways in which 'old Tibet' is represented. In doing so, these written and visual texts succeed in disrupting the selective approach that characterises state media discourses and problematize claims about 'old Tibet' as an unparalleled regime of tyranny. 


\section{九味安楪暴}

3月28日 16:19 来自 iPad客户滦

这些也是大消朝的那些事，但绝对不是清朝的全部。

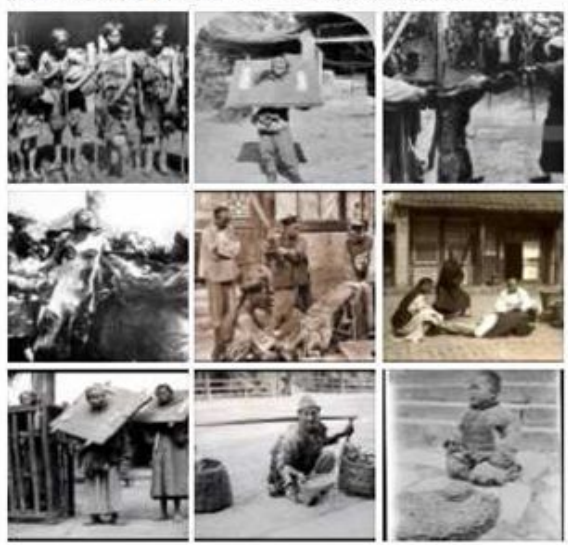

合收碳

ए 86

曰 26

Fig. 7 Nine Flavours of Anshen Tea's Weibo post on Serf Emancipation Day, 2017

Tibetan counter discourses can at times present problematic readings of Tibet's past. There is, for example, a largely uncritical and even rosy treatment of the British imperial presence in $20^{\text {th }}$ century Tibet, which was influential in enabling the PRC to eventually claim Tibet in the way that it did (McGranahan, 2017: 94). Some Tibetans also criticise these online practices for what they see as a tendency to glorify Tibet's past. As Sperling (2009b) noted, most Tibetans would indeed admit that the social structures of Tibet prior to the Chinese invasion were highly inegalitarian but would also stop far short of accepting 'the cartoonish, cruel 'Hell-on-Earth' that Chinese propaganda has portrayed it to be.' Despite some of the historical inaccuracies and idealisations of the past, Tibetan online discourses succeed in unsettling official accounts of 'old Tibet'. They thus present new opportunities for public dialogue about the selective terms of representation upon which China's regime of temporality around Tibet is built, and hold transformative potential to re-imagine Tibet's past, present and future. 


\section{Conclusion}

This article has examined written and visual online discourses of Tibetan temporality in post 2008 China. Focusing on the ways in which the Chinese state has intensified its efforts to reaffirm its legitimacy and territorial claims over Tibet in the 2008 era, I identified the convergence of power, ideology and media in representations of Tibet's past, present and future and how they work to secure Tibet within the homogenous national time of the Chinese state. I also demonstrated the ways in which visual images have become an important ideological tool in producing selective and constructed realities to reinforce official narratives about Tibet's 'proper' place within Chinese time. Following Poell's (2019) work, I argue that these discourses produce a regime of temporality that imposes upon Tibet a narrative of steady linear progression from 'hell on earth' towards Chinese socialist modernity, encasing Tibet within a totalizing Chinese national time while also constraining, and discrediting alternative narratives of the region's past, present and future. Exercising tight regulation over the possibilities of imagining Tibetan temporality, these discourses are constantly adapting to new media technologies that enable the production of increasingly sophisticated forms of propaganda to maximise online visibility, attention and audience engagement in order to consolidate state power over Tibet.

As we have seen, online spaces also provide an important site for the production and circulation of Tibetan counter discourses. By appropriating the state's penchant for visualising Tibetan temporality to evidence the 'brutalities' and 'cruelties' 
of 'old Tibet' as a feudal serfdom and 'new Tibet' as a haven of democracy, freedom and socialist modernity, Tibetans use visual images to challenge official representations, fracturing the constructed certainties of national temporality. These discourses also create important new spaces to recover and reclaim narratives that the state has actively sought to erase. Yet, apart from a few mild confrontations with state media on Weibo, these posts are often ambiguous in their overall purpose, offering little detail to explain how these images should be read or what they mean for understanding Tibet's past, present and future. In this sense, like much content across China's online spaces, 'old photo' sharing occupies 'an in-between space that is neither benign online entertainment nor overt political activism' (Yang et al, 2015: 212). Allowing Tibetans to avoid the penetrating gaze of the state while simultaneously delivering a political critique' (Thornton, 2002: 671), the ambiguity of the images also has the potential to invite viewers to make their own interpretations of the images to imagine what could have been and indeed what still could be. However, despite these creative tactics to challenge official discourses of Tibetan temporality, Tibetans continue to face various issues that diminish their capacity to gain online visibility, attention and legitimacy. Online spaces are a site of major power asymmetries. Alongside the difficulties of competing with the online resources, increasingly sophisticated tactics of digital persuasion, and the reach of the state, even greater challenges include heavy censorship and rising risks for challenging authority under President Xi Jinping. What these developments will mean for online spaces as a discursive battleground over the representation of Tibet's past, present and future remains to be seen. 


\section{Notes}

1. While the Chinese state uses 'Tibet' (Xizang) to refer to the TAR, Tibetans' use of 'Tibet' in generally covers Greater Tibet. What constitutes 'Tibet' then is a deeply political issue, with the potential to challenge or consolidate Chinese rule over Tibet and reaffirm or displace traditional Tibetan conceptions of place and nation. This issue has also been the subject of much scholarly debate (see Goldstein and Kapstein, 1998; McGranahan, 2003; Rabgey, 2006) This article uses 'Tibet' to refer to the area that encompasses Ü-Tsang, Kham and Amdo, the names of Tibet's 'three provinces' (chol kha gsum), that are now spread across the TAR, Qinghai, Sichuan, Gansu, and Yunnan, while also provided specification where necessary. In doing so, it also aims to capture the current reality of Tibet's colonisation and Tibetan sentiment about what constitutes Tibet.

\section{Bibliography}

- Anagnost, A. (1997) National Past-Times: Narrative, Representation, and Power in Modern China. Duke University Press: Durham.

- Anderson, B. (1983) Imagined Communities: Reflections on the Origin and Spread of Nationalism. London: Verso. 
- Assman, A. (2013) Transformations of the modern time regime. In: Lorenz, C. and Bevernage, B. (eds) Breaking Up Time: Negotiating the Borders Between Present, Past and Future. Göttingen: Vandenhoeck \& Ruprecht, pp.39-56.

- Bamman, D, B. O'Connor, and NA. Smith (2012) Censorship and deletion practices in Chinese social media. First Monday 17(3): 1-10.

- Bhabha, H. (1994) The Location of Culture. London: Routledge.

- Brady, AM. (2009) Mass persuasion as a means of legitimation and China's popular authoritarianism. American Behavioural Scientist 5(3): 434-457.

- Bulag, U. (2002) The Mongols At China's Edge: History And The Politics Of National Unity. Lanham: Rowman and Littlefield.

- Callaghan, W. (2004) National insecurities: Humiliation, salvation, and Chinese nationalism. Alternatives 29: 199-218.

- Caple, J. (2019) Morality and Monastic Revival in Post-Mao Tibet. Honolulu: University of Hawai'l Press.

- Castells, M. (1996) The Rise of the Network Society. Oxford: Blackwell.

- CCTV (2009) Xizang minzhu gaige 50 nian [50 years of Tibet's democratic reforms] 8 March. Available at: http://xizang.cctv.com/20090308/106971.shtml (accessed 10 June, 2019)

- CCTV (2016) Xinjiu Xizang duibi Tudan wangjiu laoren: jiu xizang shenghuo zai nongnuzhu de bianzi xia [Contrasting new and old Tibet - Elder Tudan wangjiu: Life in old Tibet under the whip of serf owners]. 12 May. Available at: 
http://news.cctv.com/2016/05/12/VIDEb6VXQdXP3JRixHBhmxXK160512.sht $\mathrm{ml}$ (accessed 20 July, 2019).

- CCTV (2017) Xinjiu Xizang duibi Yuzhen laoren: jiu Xizang gangda nongnu zhengri zhi you laozuo de fen [Contrasting new and old Tibet: Elder Yuzhen: In old Tibet the serfs just worked all day]. 5 July. Available at: http://news.cctv.com/2017/07/05/VIDE179vmDIX1sexmXDPZVCh170705.sht $\mathrm{ml}$ (accessed 20 July, 2019).

- Chakrabarty D (2000) Provincializing Europe: Postcolonial Thought and Historical Difference. Princeton: Princeton University Press.

- China Daily (2015). Full Text: Tibet's development a historical necessity. 15 April. Available at: http://www.chinadaily.com.cn/china/201504/15/content_20438892.htm (accessed 20 July, 2019).

- China Daily (2018) Tibetans celebrate Serfs' Emancipation Day. 28 March. Available at: http://www.chinadaily.com.cn/a/201803/28/WS5abb4364a3105cdcf6514da3.h tml (accessed 20 June, 2019).

- China Digital Times (2018) Minitrue: Lhasa Unrest, Consumer Rights Day. 15 March. Available at: https://chinadigitaltimes.net/2018/03/minitrue-Ihasaunrest-anniversary-world-consumer-rights-day/ (accessed 20 July, 2019).

- China Tibet News (2012) Xinjiu duibi - wu wang lishi [Contrasting old and new - Never forget history]. Available at: http://www.chinatibetnews.com/zhuanti/xinjiuxz/ (accessed 20 June, 2019). 
- Dawson, P. (2014) Reflections: On time, temporality and change in organizations. Journal of Change Management 14(3): 285-308.

- Dirlik, A. and XD. Zhang (1997) Introduction: Postmodernism and China. boundary 24(3): 1-18.

- Dodge, PSW. and L. Keränen (2018) Sixty years of 'peaceful liberation' at the Tibet Museum in Lhasa: Triumphant modernization at the rooftop of the world. Chinese Journal of Communication 11(3): 306-323.

- Dondhup, S (2017) 'Looking back at Tibetan performing arts research done by Tibetans in the People's Republic of China: Advocating for an anthropological approach.' Revue d'Etudes Tibétaines 40: 103-125.

- Espinoza, L and AP. Harris (1997) Afterward: Embracing the Tar-Baby - LatCrit Theory and the sticky mess of race. California Law Review 85(5): 1585-1645.

- Foucault, M (1970) The Order of Things: An Archaeology of the Human Sciences. New York, Pantheon Books.

- Gladney, DC. (1991) Muslim Chinese: Ethnic Nationalism in the People's Republic. Cambridge: Harvard University Press.

- Goldstein, MC. and MT. Kapstein (1998) Buddhism in Contemporary Tibet: Religious Revival \& Cultural Identity. Berkeley: University of California Press.

- Graham-Harrison, E. (2009) Tibet serf debate shadows China's 'emancipation day' Reuters, 27 March. Available at: https://www.reuters.com/article/us-chinatibet-serfs-idUSTRE52Q05U20090327 (accessed 7 June, 2019). 
- Hall, S. (1991) The Local and the Global: Globalization and ethnicity. In: McClintock, A., A. Mufti and E. Shohat (eds) Dangerous Liaisons: Gender, Nation and Postcolonial Perspectives, ed. Minneapolis: University of Minnesota, 1991, pp.173-187.

- Harrell, S. (1996) Cultural Encounters on China's Ethnic Frontiers. Seattle: University of Washington Press.

- Harris, CE. (2012) The Museum on the Roof of the World. Chicago: University of Chicago.

- Harvey, D. (1989) The Condition of Postmodernity: An Enquiry into the Origins of Cultural Change. Oxford: Blackwell.

- Hassid, J. and BC. Watson (2014) State of mind: Power, time zones and symbolic state centralization. Time and Society 23(2): 167-194.

- Hillman, B. (2014) Interpreting the post-2008 wave of protest and conflict in Tibet. Far East [Dalny Vychod] 4(1): 50-60.

- Hu, Y. (2016) BBC yiwai qi di: Yixie zhichi dalai jituan de 'xuezhe' jing ruci huangmu' BBC [BBC Unexpectedly exposed: Some 'scholars' who support the Dalai Lama clique are actually so absurd]. Tibet.cn, 1 June. Available at: http://www.tibet.cn/news/focus/1464770919493.shtml (accessed July 20, 2019).

- Jordheim, H. 2014. Introduction: Multiple times and the work of synchronization. History and Theory 53(4): 498-518. 
- Klimeš, O. and M. Marinelli (2018) Introduction: Ideology, propaganda, and political discourse in the Xi Jinping era. Journal of Chinese Political Science 23(3): 313-322.

- Kolås, Å. (2003) Modernising Tibet: Contemporary Discourses and Practices of “Modernity". Inner Asia 5: 17-37.

- Lu, XF. (1989) Xizang zhengban qingzhu chengli sanshi zhuonian [Tibet Political Consultative Conference Celebrates its $30^{\text {th }}$ Anniversary of Establishment]. People's Daily, 12 December.

- Makley, C. (2018) The Battle for Fortune: State-led Development, Personhood and Power among Tibetans in China. New York: Cornell University Press.

- McGranahan, C. (2003) From Simla to Rongbatsa: The British and the 'Modern' Boundaries of Tibet. The Tibet Journal 28(4): 39-60.

- McGranahan, C. (2017) Imperial but not colonial: Archival truths, British India, and the case of the 'naughty' Tibetans. Comparative Studies in Society and History 59(1): 68-95.

- Mignolo, WD. (2002) The geopolitics of knowledge and the colonial difference. The South Atlantic Quarterly 101(1): 57-96.

- Mitchell, TJ, (1991). The limits of the state: beyond statist approaches and their critics. American Political Science Review 85(1): 77-96.

- Morcom, A. (2018) The political potency of Tibetan identity in pop music and dunglen. Himalaya 38(1): 127-144. 
- People's Daily (1959) Ping suowei ‘Dalai lama de shengming [Comments on the so-called Dalai Lama's Statement]. April 21.

- People's Daily (1952) Qingnian tuan Xizang difang gongzuo weiyuanhui wuyue siri chengli [Communist Youth regional work committee established in Tibet on May $\left.4^{\text {th }}\right]$. May 20.

- People's Daily (2008a) Xizang zhengjiao heyi fengjian nongnu zhi yu zhong shiji Ou nongnu zhi [Tibet's theocracy and feudal serfdom, and medieval Europe's serfdom]. 15 April. Available at: http://politics.people.com.cn/GB/1026/7119853.html (accessed 20 July, 2019).

- People's Daily (2008b) Zu tu: Fengjian nongnu zhi xia de beican xizang [Image Collection: Tragic Tibet under the system of feudal serfdom]. 17 April. Available at: http://politics.people.com.cn/GB/1026/7132763.html (accessed 20 July, 2019).

- People's Daily (2009) Deguo ‘jiaodian’ zazhi: Zhu Weiqun bu chongxu guoji ganyu Zhongguo neizheng [German magazine 'perspective': Zhu Weiqun will not allow international interference in internal affairs]. 17 October. Available at: http://politics.people.com.cn/GB/1027/10208637.html (accessed 20 July, 2019).

- People's Daily (2013) Zhaxi Wangdui lao ren: jiu Xizang fuqin he gege bei lingzhu canhai zhi si [Old man Zhaixi Wangdui: In old Tibet his father and older brother were beaten to death by lord]. 21 October. Available at: http://tv.people.com.cn/n/2013/1031/c150716-23393964.html (accessed 20 July, 2019). 
- People's Daily (2015) Zhengui lishi dang'an jianzheng: Xizang fengjian nongnu zhi shi renlei fazhan shishang zui hei'an de yi ye [Valuable historical cases and evidence: The feudal serfdom was one of the darkest pages in the history of humankind's development. 28 March. Available at: http://pic.people.com.cn/n/2015/0328/c1016-26763952.html (accessed 20 July, 2019).

- People's Daily (2019) China issues white paper on democratic reform, achievements in Tibet. 27 March. Available at: http://en.people.cn/n3/2019/0327/c90000-9561297.html (accessed 20 July, 2019).

- Poell, T. (2019) Social media, temporality, and the legitimacy of protest. Social Movement Studies: 1-16.

- Powers, J. (2004) History as Propaganda: Tibetan Exiles versus the People's Republic of China. Oxford: Oxford University Press.

- Rabgey, L. (2006) Engendering Tibet: Narration, Nation and the Woman's Body in Transnational Diaspora. Ph.D. thesis, University of London.

- Rabgey, T. (2008). Newtibet.com: Citizenship as Agency in a Virtual Tibetan Public. In: Robert Barnett and Ronald Schwartz (eds) Tibetan Modernities: Notes from the Field on Cultural and Social Change. Leiden: Brill, 333-352.

- Repnikova, M. (2017) Media openings and political transitions: glasnost versus yulunjiandu. Problems of Post-Communism 64(3-4): 141-151. 
- Robin, F. (2012) Fire, flames and ashes: How Tibetan poets talk about selfimmolations without talking about them. Revue d'Etudes Tibétaines 2(5): 123131.

- Schein, L. (1997) Gender and internal orientalism in China, Modern China 23(1): 69-98.

- Shakya, T. (1999) The Dragon in the Land of Snows: A History of Modern Tibet Since 1947. London: Pimlico.

- Shakya, T. (2012) Self-immolation, the changing language of protest in Tibet. Revue d'Etudes Tibétaines. 25: 19-39.

- Shirk, SL. (2011) Changing media, changing China. In: Shirk SL (ed) Changing Media, Changing China. Oxford: Oxford University Press, pp.3-37.

- Sperling, E. (2009a) Tibet and China: The interpretation of history since 1950, China Perspectives 3.

- Sperling, E. (2009b) Tibet as ‘hell on Earth'. Info Buddhism, 27 March. Available at: https://info-buddhism.com/Tibet_as_Hell_on_Earth_Elliot_Sperling.html (accessed 7 July, 2019).

- Sriwimon, L. and PJ. Zilli (2017) Applying Critical Discourse Analysis as a conceptual framework for investigating gender stereotypes in political media discourse, Kasetsart Journal of Social Sciences 38(2): 136-142.

- Sun, WN. (2001) Media events or media stories? Time, space and Chinese (trans)nationalism. International Journal of Cultural Studies 4(1): 25-43. 
- Tai, QQ. (2014) ‘China’s media censorship: A dynamic and diversified regime. Journal of East Asian Studies 14: 185-209.

- Thornton, P. (2002) Framing dissent in contemporary China: Irony, ambiguity and metonymy. The China Quarterly 171: 661-681.

- The Tibet Album. http://tibet.prm.ox.ac.uk/ (accessed on July 20, 2017)

- Tibet Daily (2018) Meiyou gongchandang jiu meiyou xin Xizang [Without the Communist Party there would be no new Tibet]. 29 March. Available at: http://epaper.chinatibetnews.com/xzrb/html/2018-03/29/content_824420.htm (accessed 20 June, 2019).

- Tibet.cn (2019) Xizang minzhu gaige diyi cun changxiang 'wo he wo de zuguo' [Tibet's First village of democratic reform sing 'Me and My Motherland']. 28 March. Available at: http://www.tibet.cn/cn/news/zx/201903/t20190328_6536744.html (accessed 20 July, 2019).

- Tu, HJ., TT. Zhao, and N. L (2015) Duibi yu kuangjia: 'Xinjiu Xizang duibi' de neirong fenxi [Contrast and framing: content analysis of 'Contrasting New and Old Tibet.' Southeast Communication [Dongnan chuanbo] 10: 66-67.

- van Leeuwen, T. and C. Jewitt (2001) Introduction. In: van Leeuwen T and Jewitt C (eds) The Handbook of Visual Analysis. London: Sage, pp.1-9.

- Wang, JY. (2014) Criticising images: Critical discourse analysis of visual semiosis in picture news.' Critical Arts 28(2): 264-286.

- Warner, CD. (2011) A miscarriage of history: Wencheng Gongzhu and SinoTibetan historiography. Inner Asia 13: 239-64. 
- Wodak, R. (1995) Critical linguistics and critical discourse analysis. In: Verschueren J, JO. Ostman, and J. Blommaert (eds) Handbook of Pragmatics. Amsterdam: Benjamins, 204-210.

- Wu, H. (2005) Remaking Beijing: Tiananmen Square and the Creation of a Political Space. London: Reaktion Books.

- Xinhua (2008) Xizang lishi: Fengjian nongnu zhixia zangmin de beican shenghuo [Tibetan history: the tragic Life of Tibetan people under feudal serfdom]. 30 April. Available at: http://news.xinhuanet.com/photo/200804/30/content_8080195_14.htm (accessed 20 July, 2019).

- Xinhua (2009) Hei'an, canku de jiu Xizang nongquan fengjian zhidu [The dark, brutal serfdom system of Old Tibet]. 20 January. Available at: http://news.xinhuanet.com/photo/2009-01/19/content_10685678_1.htm (accessed 20 July, 2019).

- Xinhua (2019) 60 years on, democratic reform leads to a modern Tibet. 27 March. Available at: http://www.xinhuanet.com/english/201903/27/c_137928185.htm (accessed 20 July, 2019).

- Yang, PD, LJ. Tang and X. Wang (2014) Diaosi as infrapolitics: scatological tropes, identity-making and cultural intimacy on China's Internet. Media, Culture and Society $37(2): 197-214$

- Yeh, ET. (2009) From wasteland to wetland? Nature and nation in China's Tibet. Environmental History 14: 103-37.

- Zhang, Jingwu, (1957) Wei jianshe zuguo, jianshe xin Xizang er nuli. [Work hard to build the motherland and build a new Tibet]. May, 24. 
- Zeren, LL. (2013a) 1900 niandai de Lasa jiuzhao [Old photographs of Lhasa in the 1900s]. Tibetcul Blog, 15 March. Available at: http://blog.tibetcul.com/home.php?mod=space\&uid=7561\&do=blog\&id=19616 0 (accessed 10 June, 2019)

- Zeren, LL. (2013b) 1940 niandai Lasa shimao jiu zhao [Old photographs of Lhasa: Fashion in the 1940s]. Tibetcul Blog, 17 March. Available at: http://blog.tibetcul.com/home.php?mod=space\&uid=7561\&do=blog\&id=19629 2 (accessed 10 June, 2019)

- Zhu, Y. (1989) Zangzu shi Zhonghua minzu yi bufen [Tibetans are a part of the Chinese nation]. People's Daily, 28 December. 